\title{
Do foreign aid triggers economic growth in Chad? A time series analysis
}

\author{
Dervis Kirikkaleli ${ }^{1} \mathbb{B}$, Ibrahim Adeshola $2^{2^{*}}$, Tomiwa Sunday Adebayo ${ }^{3}$ and Abraham Ayobamiji Awosusi ${ }^{4}$
}

\begin{abstract}
This study explores the nexus between foreign aid and Chad's economic growth. Empirical evidence is based on annual data from 1982 to 2018. The study used ARDL, FMOLS, and DOLS techniques to establish interconnection among the economic indicators. Subsequently, the study utilized the wavelet coherence technique to capture causality and correlation between economic growth and the independent variables. One of the wavelet approach's uniqueness is that it shows the pattern and behavior of the variables used, including the different time horizons. Thus, we explore the dynamic influence of gross capital formation, foreign aid, import, and export on Chad's economic growth. The result of the ARDL long-run estimates reveals that gross capital formation and foreign aid exert insignificant impact on GDP growth. However, exports and imports exert a positive and significant impact on GDP growth. Furthermore, the global financial crisis has a negative and significant impact on the economy of Chad. The outcomes of the wavelet coherence test provide supportive evidence for the ARDL long-run outcomes. Hence, we suggested that substantial macroeconomic reforms and economic liberalization initiatives will help in the dissemination of information and promote domestic investment and importation of high-tech goods.
\end{abstract}

Keywords: Economic growth, Foreign Aid, ARDL, FMOLS, DOLS, Wavelet coherence

\section{Introduction}

Domestic saving plays a major role in economic growth, but the limitation of sufficient saving tends to impede the targeted growth which is largely experienced by less developing countries. However, foreign aid can be a vital capital flow to bridge this gap. Some countries in Africa experience are experiencing an increase in growth over the last decade due to access to cheap capital and an increase in commodity price. However, growth has slowed enormously, and the development of a more dynamic environment is much more demanding because there is a lack of resource-dynamic exporting industries that can create the changes that the resource sector cannot achieve anymore. Since the introduction of the millennium development goals (MDGs) by the United

\footnotetext{
*Correspondence: Ibrahim.adeshola@emu.edu.tr

2 Department of Information Technology, School of Computing and Technology, Eastern Mediterranean University, North Cyprus, Mersin 10, Turkey

Full list of author information is available at the end of the article
}

Nations (UN), aimed at reducing the global poverty level by half by 2015, the official development assistance (ODA) continues to increase over time. For instance, donors' ODA had rapidly increased from $\$ 86.086$ billion in 2004 to $\$ 161.517$ billion in 2014 [66, 67]. Africa remains a major recipient of aid due to its high level of poverty rate which is caused by political instability, insecurity, weak economic and financial institutions, high level of corruption, the unfriendly regulatory environment for the private sector, lack of proper governance, etc. [64]. Donors of foreign aid can either be bilateral, multilateral, or private. These donors give foreign aids to recipient countries for the following reasons: humanitarian purpose, commercial or economic purpose, strategic or political purpose. There are different kind of aid that relates with trade: (i bilateral aid from a donor-recipient pair with a positive impact on bilateral trade relations,(ii bilateral aid from all other donors to a single recipient with a possibly trade-diverting (negative impact on an existing bilateral trade relation), and (iii multilateral 
aid to a single recipient with presumably no impact on existing bilateral trade relations [42]. The role of foreign aid is to promote economic activity and strengthen the recipient countries' conditions. However, a question keeps arising over the year is what been the impact of foreign aid on the economic growth of recipient countries? In answering this question, numerous studies have been conducted with mixed views on this research topic provided by many scholars. Researchers [10, 40, 41, 54] suggest that foreign aid helps to improve the economy positively, while other scholars $[7,8,28]$, assert that foreign aid has a negative impact on economic growth, and finally, other studies $[1,18]$ propose it has no significant effect on economic growth. However, the relationship or effect of foreign aid on economic development or growth has been controversial. Studies conducted by [32, 58] emphasized that the macroeconomic policy of a country plays a significant role in making foreign aid effective. However, another study $[36,65]$ provides a contrary opinion that good policy is not required to cause foreign aid to be effective.

Chad is a landlocked country situated in Central Africa, with about 15.9 million people [66, 67]. About $66.1 \%$ of its population lives in extreme poverty [62] where the average income made annual is $\$ 740$ [21]. In the 2018 Human Development Index, Chad was ranked 187th among 189 nations [62]. Chad has a population of about 15 million, which comprises $47.43 \%$ of the population are below 14 years, $19.77 \%$ of her population between the age of $15-24$ year, $27.14 \%$ between the age of $25-54,3.24 \%$ within 55-64 year, and remaining percentage are within the year of 65 and above (World Bank, 2020). Chad's major export is crude oil and agricultural product such as gum arabic, cattle, and cotton while import machinery, an industrial product from advanced countries such as France, China, and United State. A climate-related disaster such as flooding and drought, civil war, insurgency attacks aggravate Chad's hunger and poverty. A strategic review of Chad's zero hunger 2017 identified crucial gaps in resolving the hunger and malnutrition challenges. These disastrous situations are responsible for the country having the lowest life expectancies and the highest death rate globally. Chad has become a refugee sanctuary to citizens of neighboring countries such as Sudan, Central African Republic, and Nigeria providing shelter for about 450,000 internally displaced people, about $4 \%$ of her population $[66,67]$. Chad's highest Gross Domestic Product (GDP) was about \$13.49billion in 2014 due to an increase in the oil price over the years. The fall in oil prices in 2016 and 2017 severely affected the Chad economy [21]. However, Chad's GDP increased by $2.3 \%$ in 2018 and 3.2\% in 2019 [66, 67]. Chad is a country with a debt burden of about \$3billion [66, 67], limited or weak infrastructure, lack of skilled workers, public bureaucracies in the government, and corruption [17]. Based on the problems the country is facing, the influence of foreign aid on the economic growth of Chad cannot be ignored. According to the World Bank [66, 67], the amount of foreign aid coming from different donors increased from \$391 million in 2014 to $\$ 875$ million in 2018.

Therefore, this study's major objective is to examine the impact of foreign aid on Chad's economy. This study employs the ARDL, FMOLS, and wavelet coherence technique to establish this association. This study fills the gap in the literature by exploring the effect of foreign aid on Chad's economic growth. This study employed the wavelet approaches to examine the underlying intrinsic characteristic of foreign aid and Chad's economic growth. One of the wavelet approach's uniqueness is that it can capture causality and interconnection between series at different frequencies and time-periods. The wavelet coherence has not been employed to examine the effect of foreign aid on economic growth in the case of Chad. This study will be beneficial to policymakers in chad as well as to donors to understand the efficacy and strength of foreign aid on economic growth in Chad. The remaining part of this paper is structured as follows: section "Literature review" discusses the previous review of literature, section "Methods" discusses data sources and methodology, section "Results and discussion" highlights the findings of our study, section "Conclusion" presents the conclusion with some policy implications.

\section{Literature review}

Nowadays, the majority of developed countries offer aid to developing and least developing countries. Many developed countries engage in foreign aid to pursue foreign policy objectives, where it is expected to serve as a means of transferring capital from developed economies to developing ones for development and finance [13]. Some low-income Africa's countries rely heavily on foreign aid for sustainability. This is not surprising as Evelyn and Bruno [23] reported that 69 percent of least developed countries (LDCs), 85 percent of the heavily indebted emerging countries (HIPCs), and 69 percent of low-income food-deficit countries (LIFDC) are in sub-Saharan Africa. The United Nations recognized the unique needs of the LDCs, and three conferences were organized on LDCs growth in the last 30 years, named "Programme of Actions" 1981, 1990, and the "Brussels Declaration and Programme of Action for the LDCs" (BPoA) in 2001. The main aim of the conferences was to alleviate the weak economic growths in LDCs, improve economic trends, and mitigate the poverty rate [56]. The BPoA suggested that the sustainable growth of LDCs output depends more on international demand for exports 
and the use of the latest technology for LDCs to keep up with international markets. According to BpoA perspectives on LDCs, the expatriate community has been motivating the LDCs to embrace export-oriented development strategies, free trade policy, and foreign direct investment regimes. The exports of goods in LDCs and foreign direct investment increase foreign exchange earnings, reduce the unemployment rate, facilitate imports of capital goods, increase competition in local production, and lead to efficiency in production and the optimum allocation of resources. Nevertheless, foreign aid to LDCs increased by $6.9 \%$ in real terms from 2014, and by $83 \%$ from 2000, and amounted to 145.7 billion USD in 2015 $[38,50]$. However, bilateral aid provided by one country to another risen by $4 \%$ in real terms [50]. Besides, there is a concern in the literature that aid has struggled to stimulate growth, and there are several concerns under scrutiny about the efficacy of aid in terms of real growth. However, each study gave different reasons for supporting this claim. The United States has assisted the Chadian government to foster regional security and stability for the past few years. Chadians face one of the world's highest maternal mortality rates, high child mortality, and life expectancy of fewer than 50 years. Many Chadians are food-deprived and do not access the food they need for their basic nutrition regularly. Therefore, United States Agency for International Development (USAID) has partnered with the United Nations World Food Program to provide food to poor people in Chad. The organization is also supplying funds by getting the seeds they need to produce more food to support hungry families and farmers [45]. In addition, International Fund for Agricultural Development has expanded its aid programs to vulnerable rural Chadians in order to overcome poor infrastructure, low rainfall, and climate changes [29].

Chad's economy remains heavily dependent on the oil industry, which receives the majority of inflows from foreign direct investment (FDI). The bulk of FDI has been stated to go toward oil exploration and construction of infrastructure. The services sector has also recently attracted foreign investment, mainly through the telecommunications and banking sectors, with Nigeria, France, the United Kingdom, and South Korea as the key investors in the region. Chad's FDI inflows rose from USD 461 million in 2018 to USD 567 million in 2019 [63]. According to Asongu and Nwachukwu [14], foreign aid deteriorates economic growth and institutional governance of least developed countries benefiting from foreign aid as it creates more dependency and weakens domestic governance. Besides, Dong and Fan [18] also confirmed that overseas open direct investment (ODI) of China to 47 African countries plays no significant role in the 47 African countries' economic growth while their foreign aid to those countries significantly enhances China's economic growth. However, Tekin [57] findings on economic growth, foreign aid, and trade openness in low-income countries provide mixed results. The investigator established that foreign aid has a negative impact on both Chad and the Gambia economic growth, while foreign aid exerts an insignificant impact on the economic growth of other countries. Ee [19] panel analysis between export led-growth and economic growth in four Sub-Saharan African countries revealed that exports significantly have a positive impact on economic growth. Fashina et al. [24] also investigate the connection between foreign assistance and human capital, and economic growth in Nigeria. Their findings indicate that a sustained increase in foreign aid flows beyond optimal point could adversely affect economic growth. Similarly, Yiew and Lau [68] empirically explore the role and the effect of foreign aid on economic growth using 95 developing countries by considering foreign direct investment and population as the control variables. The outcomes of their analysis revealed that foreign aid negatively affects economic growth. In addition, Tang and Bundhoo [55] analyse the relationship between international aid and economic growth of the 10 largest foreign aid recipients in Sub-Saharan Africa for a period of 23 years from 1990 to 2012. The authors found that the aid does not have a substantial effect on economic growth (Figs. 1,2).

Similarly, Ouedraogo and Sourouema [46] investigate the impact of export concentration on fiscal procyclicality in 40 sub-Saharan Africa. Their empirical outcomes show that the diversification of exports could help sub-Saharan African countries to run countercyclical fiscal policy (reduce spending and raising taxes during a boom period, and increase spending and cutting taxes during a recession) as there is a significant relationship between export, pubic investment, and economic growth. The authors further suggested that sub-Saharan African countries should consider implementing policies that would diversify exports and stabilize export earnings and economic growth. The study of Pham and Pham [50] on the effect of foreign aid on economic growth revealed that foreign aid does not guarantee economic growth as it depends strongly on the manners the aid is used and on the absorptive capacity of these recipient's countries, as well as their initial development. By categorizing foreign aid into three main categories: education, health, and agriculture, Maruta et al. [38] examined the influence of sectoral foreign aid and institutional quality on the economic growth of 74 developing countries from Africa, Asia, and South America between 1980 and 2016. Their outcomes show that education aid is significant to South America's economic growth, health aid is significant to Asia, and agricultural aid is more significant in Africa's 
economic growth as well, while other types of sectoral aid have a negative effect on their economic growth. We have systematically reviewed the prior studies, and the findings are mixed. Furthermore, some studies failed to provide clear-cut, substantial evidence in support of aid effectiveness. To extend the debate on foreign aid, this paper investigates the effect of foreign aid on economic growth and also the role of gross capital formation, import, and export in Chad. Chad has become a strategic partner for Western leaders and coalitions in the fight against terrorism in its borders, Libya and Sudan. Chad is rich in gold, uranium, and in the year 2003, they became an oil-exporting state. Notwithstanding its wealth, it struggles from poor services, internal strife, and adverse socioeconomic conditions [27]. In addition, Chad appears more affected by the resource curse than are other developing countries, despite their vast oil wealth. Financial challenges related to revenue generation and extraction-related management, especially in oil production, followed by accidental crude oil spills and social challenges related to the living standards and wellbeing of people are some of the problems facing Chad [25]. Little is known about the effect of foreign aid on the economic growth of chad. Table 1 below summarizes the last five years' studies on the Aid-Growth relationship by indicating the country(s) under investigation, variables used, econometric techniques used, period investigated, and the findings derived.

\section{Methods}

This study's main objective is to investigate the impact of foreign aid on the economic growth of Chad using the time series data ranging from 1982 to 2018, which was obtained from World Bank database. Based on the study objective, we propose the economic function as follows in Equation;

$$
\mathrm{GDP}=\mathrm{f}(\mathrm{ODA}, \mathrm{GCF}, \mathrm{IMP}, \mathrm{EXP})
$$

These variables were transformed into a logarithm solely for our model's uniformity, which is good for our estimation. The empirical model for our study is shown below:

$$
\mathrm{GDP}=\beta_{0}+\beta_{1} \mathrm{ODA}+\beta_{2} \mathrm{GCF}+\beta_{3} \mathrm{IMP}+\beta_{4} \mathrm{EXP}+\mu_{\mathrm{i}}
$$

In the Eq. 2 above, economic growth is depicted as GDP per capita; the foreign aid received by the country is illustrated as ODA; GCF represents gross capital formation (investment); IMP and EXP represent import and export as percentage of GDP, respectively; the error term is represented as $\mu_{i}$.

To accomplish the objective of this study, we employed the ARDL bounds test proposed by Peseran et al. (2001).
It is essential to ensure that all variables used are not integrated at $I(2)$; for this reason, the following stationarity tests were employed: ADF, PP, DF-GLS, and KPSS. Furthermore, Zivot and Andrews [70] and Lee and Strazicich [35] structural break. Since the ARDL bound test is built on the ordinary least squares (OLS) estimation, which utilizes a conditional unrestricted error correction model to define the cointegration among the variables used. Equation (3) below shows the ARDL model, which was designed to align with the motive of our study:

$$
\begin{aligned}
\Delta G D P_{t} & =\vartheta_{0}+\sum_{i=1}^{t} \vartheta_{1} \Delta O D A_{t-i}+\sum_{i=1}^{t} \vartheta_{2} \Delta G C F_{t-i} \\
& +\sum_{i=1}^{t} \vartheta_{3} I M P_{t-i}+\sum_{i=1}^{t} \vartheta_{4} \Delta E X P_{t-i} \\
& +\sigma_{1} G D P_{t-1}+\sigma_{2} O D A_{t-1} \\
& +\sigma_{3} G C F_{t-1}+\sigma_{4} I M P_{t-1} \\
& +\sigma_{5} E X P_{t-1}+\sigma_{6} D U M_{t-1}+\mu_{t}
\end{aligned}
$$

When there is cointegration, Eq. (3) could be written as follows:

$$
\begin{aligned}
\Delta G D P_{t}= & \vartheta_{0}+\sum_{i=1}^{t} \vartheta_{1} \Delta O D A_{t-i}+\sum_{i=1}^{t} \vartheta_{2} \Delta G C F_{t-i} \\
& +\sum_{i=1}^{t} \vartheta_{3} I M P_{t-i}+\sum_{i=1}^{t} \vartheta_{4} \Delta E X P_{t-i} \\
& +\sigma_{1} G D P_{t-1}+\sigma_{2} O D A_{t-1}+\sigma_{3} G C F_{t-1} \\
& +\sigma_{4} I M P_{t-1}+\sigma_{5} E X P_{t-1}+\sigma_{6} D U M_{t-1} \\
& ++\sigma_{7} E C T_{t-1}+\mu_{t}
\end{aligned}
$$

In Eqs. 3 and $4, \sigma_{i}(\mathrm{i}=1 \ldots 0.7)$ represents the short-run coefficients of the variable used, $\vartheta_{i}(\mathrm{i}=0 \ldots \ldots . .0 .4)$ depicted the long-run coefficients of the variable used, $t$ represents the lag length, DUM signifies the dummy variable, which captures the global financial crisis. ECT denotes the error correction model. This study employed the ARDL bound test due to the Pesaran, and Shin [48] and Pesaran et al. [49], argument which was cited in Ayobamiji and Kalmaz [16] that this method can accommodate different lags for the variable used, the method is also applicable when the nature of stationarity is integrated at the order $I(0)$ and $1(1)$, unlike other conventional cointegration tests, the method could accommodate both the long and shortrun in a single equation, the method also removes the problem of autocorrelation and finally, the method can 
Table 1 Studies synopsis

\begin{tabular}{|c|c|c|c|c|c|}
\hline Author(s) & Country(S) & Variable(s) Used & Econometric Technique & Period & Findings \\
\hline Alam and Bhowmik [9] & Bangladesh & $Y, I M P, E X P, G C F$ & $\begin{array}{l}\text { VECM, Granger causality } \\
\text { test }\end{array}$ & $1972-2018$ & $\begin{array}{l}\text { Significant relationship } \\
\mathrm{EXP} \rightarrow \mathrm{Y} \\
\mathrm{IMP} \rightarrow \mathrm{Y} \\
\mathrm{GCF} \rightarrow \mathrm{Y}\end{array}$ \\
\hline Awan and Qasim [15] & Pakistan & $\begin{array}{l}\text { Y, IMP, EXP, ED, GCF, DS, } \\
\text { POP }\end{array}$ & ARDL & 1980-2017 & $\begin{array}{l}\text { Insignificant relationship } \\
\mathrm{EXP} \rightarrow \mathrm{Y} \\
\mathrm{GCP} \rightarrow \mathrm{Y} \\
\mathrm{IMP} \rightarrow \mathrm{Y}\end{array}$ \\
\hline $\begin{array}{l}\text { Asongu and Nwachukwu } \\
\text { [14] }\end{array}$ & 52 African countries & $\begin{array}{l}\text { R.Q, R.L, V\&A, MLD, DAC, } \\
\text { Trade, ODA }\end{array}$ & $\begin{array}{l}\text { 2SLS, OLS, 2SLS-IV, Panel } \\
\text { Granger causality }\end{array}$ & 1996-2010 & $\begin{array}{l}\text { Negative Aid-Growth } \\
\text { relationship } \\
\text { Gov.E } \rightarrow \text { Y } \\
\text { R.Q } \rightarrow \text { Y } \\
\text { CC } \rightarrow Y \\
R . L \rightarrow Y\end{array}$ \\
\hline Ee [19] & $\begin{array}{l}\text { Four Sub-Saharan African } \\
\text { (SSA) countries }\end{array}$ & ELG & $\begin{array}{l}\text { Panel Unit Root Tests, } \\
\text { Panel Cointegration, } \\
\text { FMOLS, DOLS }\end{array}$ & $1985-2014$ & $\begin{array}{l}\text { Positive Aid-Growth } \\
\text { relationship } \\
\text { ELG } \rightarrow \text { Y }\end{array}$ \\
\hline $\begin{array}{l}\text { Ouedraogo and Sour- } \\
\text { ouema [46] }\end{array}$ & $\begin{array}{l}40 \text { sub-Saharan African } \\
\text { countries }\end{array}$ & Y, PI, EXP & $\begin{array}{l}\text { System-GMM, Huber- } \\
\text { White Sandwich, LSDV }\end{array}$ & 1995-2015 & $\begin{array}{l}\text { Positive Aid-Growth } \\
\text { relationship } \\
\mathrm{EXP} \rightarrow \mathrm{Y} \\
\mathrm{PI} \rightarrow \mathrm{Y}\end{array}$ \\
\hline Dong and Fan [18] & 47 African countries & Y, ODI, FAID & $\begin{array}{l}\text { Fixed Effect, Quantile } \\
\text { Regressions, Pooled } \\
\text { OLS, GMM, System- } \\
\text { GMM, IV Regressions }\end{array}$ & $2003-2013$ & $\begin{array}{l}\text { Significant Aid-Growth } \\
\text { relationship } \\
\text { FAID } \rightarrow \text { Y } \\
\text { Insignificant Aid-Growth } \\
\text { relationship } \\
\text { ODI } \rightarrow \text { Y }\end{array}$ \\
\hline Tekin [57] & $\begin{array}{l}14 \text { aid-dependent African } \\
\text { countries }\end{array}$ & ODA, OPENNESS, FAID & Granger Causality Test & 1970-2017 & $\begin{array}{l}\text { Insignificant Aid-Growth } \\
\text { relationship (Chad and } \\
\text { the Gambia) } \\
\text { FAID } \rightarrow \text { Y }\end{array}$ \\
\hline Maruta et al. [38] & $\begin{array}{l}74 \text { LDCs from Africa, Asia, } \\
\text { and South America }\end{array}$ & Y, eAID, aAID, hAID & 2SLS, System-GMM & 1980-2016 & $\begin{array}{l}\text { Insignificant Aid- } \\
\text { Growth Effect in } \\
\text { Africa }(\text { AID } \rightarrow \text { Y), Asia } \\
(\text { AID } \rightarrow \text { Y) and South } \\
\text { America } \\
(\text { AID } \rightarrow \text { Y) }\end{array}$ \\
\hline Sethi et al. [53] & $\begin{array}{l}\text { India } \\
\text { and Sri Lanka }\end{array}$ & Y, FAID, GCF,TR, INF, FD & $\begin{array}{l}\text { Granger Causality test, } \\
\text { VAR modeling }\end{array}$ & 1960-2015 & $\begin{array}{l}\text { Insignificant Aid-Growth } \\
\text { Effect in Sri Lanka } \\
\text { (FAID } \rightarrow \text { Y) } \\
\text { Significant Aid-Growth } \\
\text { Effect in India on the } \\
\text { Short-run (FAID } \rightarrow \text { Y) }\end{array}$ \\
\hline Jena and Sethi (2020) & South Asian countries & Y, FAID, INV, TR, PS, FD & $\begin{array}{l}\text { PDOLS, FMOLS, Granger } \\
\text { causality } \\
\text { test }\end{array}$ & 1996-2017 & $\begin{array}{l}\text { Significant Aid-Growth } \\
\text { Effect } \\
\text { FAID } \rightarrow Y \\
T R \rightarrow Y\end{array}$ \\
\hline Adebayo [2] & Nigeria & Y, GCF, FDI, EXP, GDS & $\begin{array}{l}\text { ARDL, TYGC, Variance } \\
\text { Decomposition, Wave- } \\
\text { let Coherence }\end{array}$ & $1981-2018$ & $\begin{array}{l}\text { Significant relationship } \\
\text { GCF } \rightarrow Y \\
\mathrm{EXP} \rightarrow Y \\
\mathrm{GDS} \rightarrow Y\end{array}$ \\
\hline Adams [1] & $\begin{array}{l}\text { Asian and African coun- } \\
\text { tries }\end{array}$ & Y, FAID & $\begin{array}{l}\text { Panel Data Fixed-effects } \\
\text { Model }\end{array}$ & $1980-2015$ & $\begin{array}{l}\text { Insignificant Aid-Growth } \\
\text { relationship }\end{array}$ \\
\hline Mustafa et al. [41] & Sudan & Y, ODA, HC, EXP, CRD, PRIV & ARDL & $1980-2015$ & $\begin{array}{l}\text { Significant Aid-Growth } \\
\quad \text { relationship } \\
\mathrm{ODA} \rightarrow Y \\
\mathrm{HC} \rightarrow \mathrm{Y} \\
\mathrm{EXP} \rightarrow \mathrm{Y} \\
\mathrm{CRD} \rightarrow \mathrm{Y} \\
\mathrm{PRIV} \rightarrow \mathrm{Y}\end{array}$ \\
\hline
\end{tabular}


Table 1 (continued)

\begin{tabular}{|c|c|c|c|c|c|}
\hline Author(s) & Country(S) & Variable(s) Used & Econometric Technique & Period & Findings \\
\hline $\begin{array}{l}\text { Ehigiamusoe and Lean } \\
\text { [20] }\end{array}$ & Nigeria & $\mathrm{Y}, \mathrm{FCl}, \mathrm{FDI}, \mathrm{FPI}, \mathrm{FL}$ & ARDL & $1980-2015$ & $\begin{array}{l}\text { Insignificant Aid-Growth } \\
\quad \text { relationship } \\
\mathrm{FDI} \rightarrow \mathrm{Y} \\
\mathrm{FL} \rightarrow \mathrm{Y} \\
\text { Significant Aid-Growth } \\
\quad \text { relationship } \\
\mathrm{FPI} \rightarrow Y \\
\mathrm{FCl} \rightarrow Y\end{array}$ \\
\hline Adebayo and Kalmaz & Nigeria & Y, FAID, GCF, INF & $\begin{array}{l}\text { ARDL, FMOLS, DOLS, } \\
\text { Causality, Wavelet } \\
\text { Coherence Technique }\end{array}$ & 1980-2018 & $\begin{array}{l}\text { Insignificant Aid-Growth } \\
\text { relationship } \\
\mathrm{GCF} \rightarrow \mathrm{Y}\end{array}$ \\
\hline Ali et al. [10] & Ethiopia & Y, FAID & OLS & $1991-2016$ & $\begin{array}{l}\text { Negative Aid-Growth } \\
\text { relationship }\end{array}$ \\
\hline
\end{tabular}

GOVE, Government Expenditure; P.I, Public Investment; EXP, Export; POP, Population; INV, Investment; POV, Poverty; COR, Corruption; FDI, Foreign Direct Investment;Y, Economic Growth; GCF, Gross Capital Formation; TR, Trade; CC, Control of Corruption; Gov.E, Government Effectiveness; R.Q, Regulation Quality; R.L, Rule of Law; V\&A, Voice and Accountability; Trade, Trade Openess; ELG, Export-Led Growt; FD, Financial Development; eAID, Education Aid; aAID, Agriculture Aid; hAID, Health Aid; PS, Price Stability; FD, Financial Deepening; GDS, Gross Domestic Savings; CRD, Banking Credit; HC, Human Capital; PRIV, Privatization; FPI, Foreign Portfolio Investment; $\mathrm{FCl}$, Foreign Capital Inflow

Source: Authors' Compilation

be implemented for small sample size $[29,34,52]$. The F-statistic constructed by Pesaran et al. [49] was used to verify the cointegrating relationship between the variable used. The null hypothesis depicts that a no cointegrating relationship, while the alternative hypothesis depicts the presence of cointegration. In a situation, when the F-statistics exceeds both the lower and upper critical bound level at a reasonably significant level ${ }^{1}(1 \%, 5 \%$, and $10 \%)$. This shows that there is evidence of a cointegrating relationship between the dependent and independent variables indicating that the null hypothesis should be rejected and vice versa.

This study employs the Breusch-Pagan-Godfrey heteroscedasticity in detecting the problem of heteroscedasticity; Jarque-Bera test to detect the normality distribution test of the model; Breusch-Godfrey Serial Correlation LM test to discover the presence of serial correlation; Ramsey RESET to determine the adequacy of the model, and the CUSUM and CUSUMSQ were used in detecting the ARDL model stability. All these tests are employed for a diagnostic test.

Fully Modified Ordinary Least Squares (FMOLS) and Dynamic Ordinary Least Squares (DOLS) have been employed, mainly to check the robustness of the variable coefficients in the long-run in the ARDL result. FMOLS was originally employed by Phillips and Hansen [51], this method provides the benefits of erasing longrun correlation problems between stochastic regressors

\footnotetext{
${ }^{1}$ In economics and finance, three significance level (1\%, 5\% and 10\%) are commonly used when rejecting and accepting the hypothesis. Based on that we used these three significance level in this research. Though in business and management studies, $5 \%$ is commonly accepted.
}

innovation and cointegrating equations while the DOLS was employed so as to deliver estimates which are efficient and unbiased in nature for a small sample size.

To further achieve the objective of this study, we explored the time-frequency dependence of the impact of foreign aid on Chad's economic growth using the wavelet approach, especially the wavelet coherence techniques. The wavelet approach was initially employed by Goupillaud, Grossmann, and Morlet [26]. This wavelet coherence approach is becoming popular and accepted in economic and finance literature. The wavelet approach results are very reliable compared to the other conventional causality-based time-domain approach that tends to suffer from chaotic behavior and nonlinearity [43]. The major novelty of this approach is that it can capture causality and interconnection between series at different frequencies and time periods. This study employed the Morlet wavelet family ( $(t)$ approach, which follows the transformation of the central frequency into the Fourier sine and cosine from Gaussian windows and is defined as follows.

$$
\varpi(t)=\pi^{-\frac{1}{4}} e^{-i \varpi t} e^{-\frac{1}{2} t^{2}} p(t), n=0,1,2,3 \ldots \mathrm{N}-1, \mathrm{iis} \sqrt{-1} .
$$

where: $\varpi$ represents the observed functional; $\pi^{-\frac{1}{4}}$ represents the normalized factor; $e^{-i \varpi t}$ is the standard deviation of the Gaussian unit, and $e^{-\frac{1}{2} t^{2}}$ represents the complex sinusoid.

$k$ and $f$ are the two major features of wavelets, which are depicted as time and frequency. By transforming $\varpi$, $\varpi_{k, f}$ is being formed. $\varpi_{k, f}$ is well-defined by the following notation: 
Table 2 Unit root without break

\begin{tabular}{|c|c|c|c|c|c|c|}
\hline Variables & $A D F_{K \& T}$ & Order & $P P_{K \& T}$ & Order & $K P S S_{K \& T}$ & Order \\
\hline GDP & $-5.502^{*}$ & $/(1)$ & $-5.507^{*}$ & $/(1)$ & $0.126^{* * *}$ & $\mathrm{I}(0)$ \\
\hline ODA & $-6.561^{*}$ & $/(1)$ & $-6.561^{*}$ & $/(1)$ & $0.138^{* * *}$ & $\mathrm{I}(0)$ \\
\hline GCF & $-4.881^{*}$ & $/(1)$ & $-4.834^{*}$ & $/(1)$ & $0.126^{* * *}$ & $\mathrm{I}(0)$ \\
\hline IMP & $-6.367^{*}$ & $/(1)$ & $-6.354^{*}$ & $/(1)$ & $0.166^{* *}$ & $\mathrm{I}(0)$ \\
\hline EXP & $-4.433^{*}$ & $/(1)$ & $-4.450^{*}$ & $/(1)$ & $0.124^{* * *}$ & $\mathrm{I}(0)$ \\
\hline
\end{tabular}

${ }^{*}, * * \& * *$ illustrates indicators significance at $1 \%, 5 \%$, and $10 \%$ level

Source: Authors' compilation

$$
\varpi_{k, f}(t)=\frac{1}{\sqrt{h}} \varpi\left(\frac{t-k}{f}\right), k, f \in \mathbb{R}, f \neq 0
$$

The continuous wavelet transformation (CWT) was employed to identify the time series's components (either high or low) by estimating both the dependence of timefrequency and decomposing signal into wavelet. The CWT was built following this notation:

$$
\varpi_{p}(k, f)=\int_{-\infty}^{\infty} p(t) \frac{1}{\sqrt{f}} \varpi\left(\frac{t-k}{f}\right) \mathrm{dt},
$$

where $\varpi$ represents the continuous wavelet, $k$ represents the scale's function, and $f$ depicts the time series, $p(t)$ depicts the initial times series, and $\varpi$ represents the Eq. (8) coefficient

$$
p(t)=\frac{1}{C_{\varpi}} \int_{0}^{\infty}\left[\int_{-\infty}^{\infty}\left|\mathfrak{w}_{p}(a, b)\right|^{2} d a\right] \frac{d b}{b^{2}} .
$$

Wavelet power spectrum (WPS) was used in this study to capture the volatility of the time series. The WPS is defined in Eq. (9) as follows:

$$
\operatorname{WPS}_{p}(k, f)=\left|W_{p}(k, f)\right|^{2}
$$

The wavelet coherence approach is the major wavelet tool employed in this study because it is used in examining the causality and correlation between our study's dependent and interdependent variables by taking into account the time and frequency-based causality together [61]. The cross wavelet transform (CWT) has to be done before the wavelet coherence is performed. However, the cross-wavelet captures the time series $p(t)$ and $q(t)$ covariance in the time-frequency-based causalities, as shown in Eq. (10):

$$
W_{p q}(k, f)=W_{p}(k, f) W_{q} \overline{(k, f)},
$$

where $W_{p}(k, f)$ and $W_{j}(k, f)$ symbolizes the CWT for $p(t)$ and $q(t)$, respectively, which was detailed by Torrence and Compo [59]. They revealed that the squared wavelet coherence $\left(R^{2}(k, f)\right)$ could be built as:

$$
R^{2}(k, f)=\frac{\left|S\left(f^{-1} W_{p q}(k, f)\right)\right|^{2}}{S\left(f^{-1}\left|W_{p}(k, f)\right|^{2}\right) S\left(f^{-1}\left|W_{q}(k, f)\right|^{2}\right)}
$$

From the above equation, $S$ denotes time, which a smoothing operator over time. $R^{2}(k, f)$ symbolized intervals within 0 and 1 . In a situation, when the $R^{2}(k, f)$ reaches 1 , it means that the time series indicators are correlated, or a causal relation occurs at a certain level between the time series indicators, which is shown as red color surrounded by a black line. However, when the $R^{2}(k, f)$ reaches 0 , it means that the time series indicators are not correlated or no causal link. $R^{2}(k, f)$ only provides the correlation strength and leaving out the direction or sign of the connection [44]. In solving this problem, Torrence and Compo [59] developed a means through the indications of deferrals in the wavering of two-time series, and it is defined as:

$$
\phi_{p q}(k, f)=\tan ^{-1}\left(\frac{\mathrm{L}\left\{\mathrm{S}\left(\mathrm{f}^{-1} \mathrm{~W}_{\mathrm{pj}}(\mathrm{k}, \mathrm{f})\right)\right\}}{O\left\{S\left(f^{-1} W_{p j}(k, f)\right)\right\}}\right)
$$

where $L$ and $O$ symbolizes the imaginary and real part operator, respectively.

Table 3 Unit root with break

\begin{tabular}{llll}
\hline Variables & $\boldsymbol{Z A}_{\boldsymbol{K} \& \boldsymbol{T}}$ & Break-Year & Order \\
\hline GDP & $-6.803^{*}$ & 2001 & $/(1)$ \\
ODA & $-6.062^{*}$ & 2001 & $/(1)$ \\
GCF & $5.545^{*}$ & 2000 & $/(0)$ \\
IMP & $5.533^{*}$ & 2001 & $/(0)$ \\
EXP & $-6.407^{*}$ & 2003 & $/(0)$ \\
\hline
\end{tabular}

* illustrates indicators significance at $1 \%$ level

Source: Authors' compilation 
Table 4 ARDL bounds test outcomes

\begin{tabular}{lll}
\hline Model estimated & Optimal lag length & F-Statistics \\
\hline GDP $=$ F(ODA, GCF, IMP, EXP, DUM) & $(4,4,4,4,3,4)$ & $18.166^{*}$ \\
ODA = F(GDP, GCF, IMP, EXP, DUM) & $(4,2,3,2,2,4)$ & $11.461^{*}$ \\
GCF $=$ F(ODA, GDP, IMP, EXP, DUM) & $(1,0,3,0,0,0)$ & $12.298^{*}$ \\
IMP = F(ODA, GCF, GDP, EXP, DUM) & $(1,0,0,0,0,0)$ & $4.132^{* *}$ \\
EXP = F(ODA, GCF, GDP, IMP, DUM) & $(3,3,3,3,2,2)$ & $5.637^{*}$ \\
Significant level & LBI I 0$)$ & UBI(1) \\
1\% level & 3.41 & 4.68 \\
$5 \%$ level & 2.62 & 3.79 \\
$10 \%$ level & 2.26 & 3.35 \\
\hline
\end{tabular}

$1 \% \& 5 \%$ significance level represents * \& **levels correspondingly. DUM mirrors the dummy variable. $L B$ and UB represent lower and upper bound, respectively

Source: Authors' compilation

\section{Results and discussion}

To explore the relationship between economic growth and foreign aid in Chad, the ARDL bounds test technique was utilized. For this technique to be utilized, variables deployed must be integrated at $I(0)$ or $I(1)$ or mixed that is $\mathrm{I}(0)$ and $\mathrm{I}(1)$. To ascertain this requirement, the $\mathrm{ADF}$, PP, and KPSS unit root tests were deployed. Though this unit root tests cannot detect structural break(s) in series. Consequently, to verify the existence of structural break in the series, the Zivot-Andrews unit root test was utilized. Tables 2 and 3 depicts the unit root tests without a structural break and unit root test with structural break correspondingly.

The outcomes illustrated in Tables 2 and 3 demonstrated that all series are integrated into $\mathrm{I}(\mathrm{I})$ or
$\mathrm{I}(0)$. Therefore, we performed the ARDL bounds test approach to determine the interconnections between GDP growth and the independent variables (foreign assistance, imports, gross capital formation, and exports) in Chad between 1982 and 2018. An appropriate lag length is required before ARDL bounds testing is estimated, and this was performed premised on AIC minimum value. Table 4 provided the results of the ARDL bounds test technique for our framework, taking into account variables structural break. At a significance level of \%, there is evidence of cointegration in the long-run between economic growth and the other independent variables. However, when other variables are used as the dependent variable, there is proof of cointegration among the variables in Chad.

Bearing in mind the existence of long-run linkages between variables deployed, we explored the dynamic influence of gross capital formation, foreign aid, import, and export on Chad's economic growth. The estimated outcomes are reported in Table 5. Findings indicate(i) no significant interaction exists between foreign aid and GDP growth in Chad. The reason for this insignificant impact of foreign aid on economic growth in Chad is because most of the foreign aid coming to least developing country such as Chad is channeled toward consumption. Foreign aid will only trigger economc growth if it is channelled toward investment which will create job opportunities and improve quality of life [3]. This result corresponds to past works [1, $15,18,30,38,53,55]$, which contradict the study done by $[7,8,10,28,40,41,54]$. (ii) gross capital formation in Chad does not influence GDP growth in Chad. This

Table 5 Long-run and short-run results

\begin{tabular}{|c|c|c|c|c|c|}
\hline Dependent variable & Analysis & Regressors & Coefficient & Error term & T-statistics \\
\hline \multirow[t]{5}{*}{ GDP } & \multirow[t]{5}{*}{ Long-run } & ODA & 0.048 & 0.059 & 0.814 \\
\hline & & GCF & 0.160 & 0.086 & 1.851 \\
\hline & & IMP & 0.179 & 0.062 & $2.862^{* *}$ \\
\hline & & EXP & 0.286 & 0.052 & $5.422^{*}$ \\
\hline & & DUM & -0.145 & 0.022 & $-6.549^{*}$ \\
\hline GDP & Short-Run & ECM(-) & -0.566 & 0.036 & $-15.66^{*}$ \\
\hline \multicolumn{6}{|l|}{ Diagnostic tests } \\
\hline$x^{2}$ Heteroscedasticity & $0.68(0.75)$ & & & & \\
\hline$x^{2}$ Ramsey & $0.77(0.49)$ & & & & \\
\hline$x^{2}$ Normality & $0.61(0.73)$ & & & & \\
\hline$X^{2} L M$ & $2.02(0.25)$ & & & & \\
\hline \multicolumn{6}{|l|}{ Stability check } \\
\hline CUSUM Test & Stable at 5\% level & & & & \\
\hline CUSUM SqTest & Stable at 5\% level & & & & \\
\hline
\end{tabular}

*,**,*** stand for $1 \%, 5 \%$, and $10 \%$ significance level correspondingly

Source: Authors' compilation 
Table 6 Robustness check for ARDL coefficients

\begin{tabular}{|c|c|c|c|c|}
\hline \multicolumn{3}{|l|}{ FMOLS } & \multicolumn{2}{|l|}{ DOLS } \\
\hline \multicolumn{5}{|c|}{ Dependent variable: GDP } \\
\hline Regressors & Coefficient & T-statistic & Coefficient & T-statistic \\
\hline ODA & 0.060 & 1.180 & 0.048 & 0.686 \\
\hline GCF & 0.030 & 0.682 & 0.015 & 0.243 \\
\hline IMP & 0.135 & $2.101^{* * *}$ & 0.189 & $2.183^{* * *}$ \\
\hline EXP & 0.484 & $16.13^{*}$ & 0.493 & $13.16^{*}$ \\
\hline DUM & -0.054 & $-14.86^{*}$ & -0.145 & $-13.67^{*}$ \\
\hline
\end{tabular}

${ }^{*},{ }^{* *},{ }^{* * *}$ stand for $1 \%, 5 \%$, and $10 \%$ significance level correspondingly

Source: Authors' compilation

\section{Exports of Goods and Services}

12

10

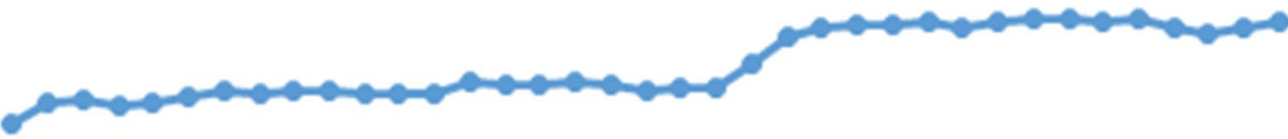

6

4

2

0

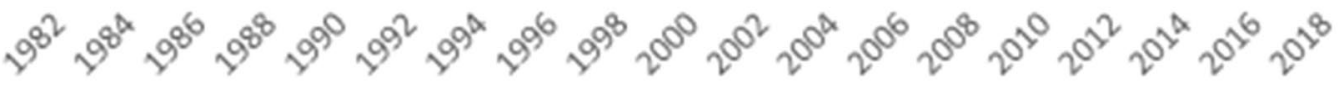

Years

Fig. 1 Trend of exports of goods and services from 1982 to 2018

result does not align with previous studies [41, 46], (iii) at a significance level of $5 \%$, there is evidence of a positive link between GDP growth and import. This indicates that a $1 \%$ increase in imports will lead to a $0.17 \%$ increase in GDP growth when other variables are held constant. This finding aligns with previous studies such as Alam and Bhowmik [9] and Awan and Qasim [15], (iv) export exert positive and significantly influence on GDP growth in Chad. This portrays that when other factors are held constant, a $0.28 \%$ increase in GDP growth results in a $1 \%$ increase in export. This result aligns with past studies [9, 19, 46]; (v) as expected, the global financial crisis has a negative ad significant impact on the economy of Chad; and (vi) the ECM is significant, statistically indicating a quicker return to equilibrium in the event of an imbalance. This term illustrates the speed of the adjustment process to go back to equilibrium. Various post estimation tests were conducted to check if the model is good. Based on tests carried out as indicated in Table 6, the model is not suffering from misspecification, and residuals are normally distributed, with no sign of heteroscedasticity and no 
Kirikkaleli et al. Futur Bus J 2021, 7(1):17

Page 10 of 17

Gross Capital Formation

12

10

8

6

4

2

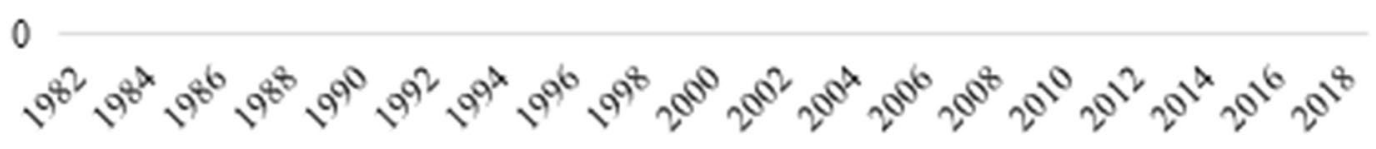

Years

Fig. 2 Trend of gross capital formation from 1982 to 2018

Imports of Goods and Services

13

12.5

12

11.5

11

10.5

10

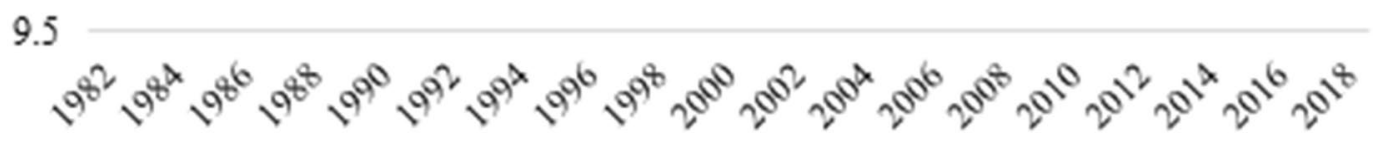

Years

Fig. 3 Trend of imports of goods and services from 1982 to 2018 


\section{Foreign Aid}

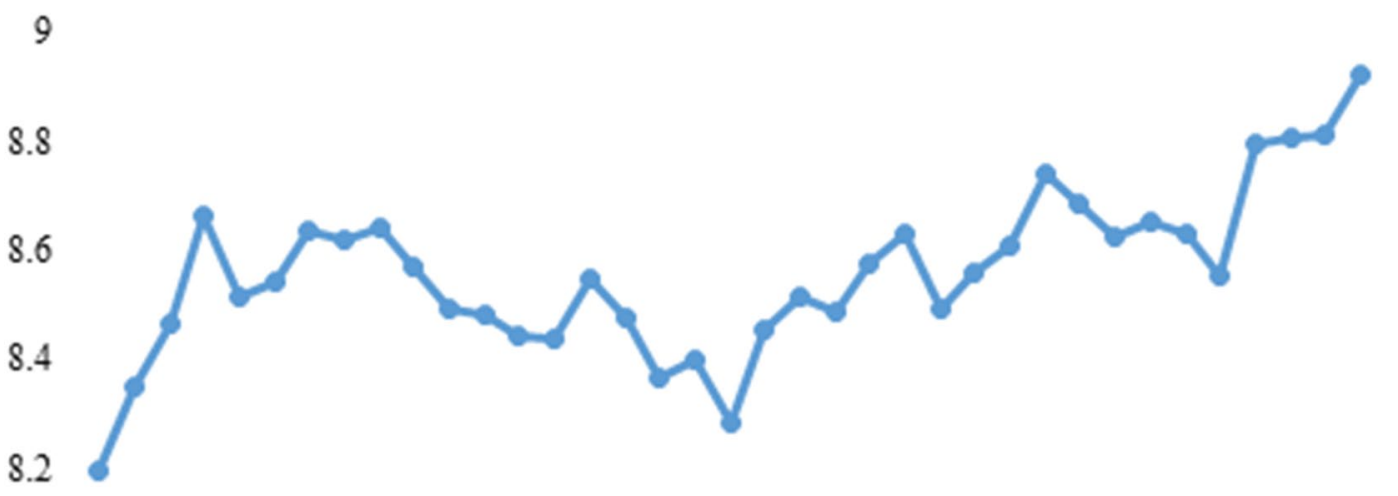

7.8



Fig. 4 Trend of foreign aid from 1982 to 2018

evidence of serial correlation. Furthermore, CUSUM and CUSUM Sq. show that the model is stable at a $5 \%$ level of significance.

Table 6 below illustrates the FMOLS and DOLS outcomes for Chad between 1982 and 2018, which is adopted as a robustness check for the ARDL long-run estimate. The outcome of these techniques is identical to the findings obtained from the ARDL technique. Thus, the finding obtained from the ARDL long-run estimate is robust.

The wavelet coherence technique was adopted to explore the correlation between economic growth and its determinants in Chad. Figures 3,4,5, and 6 show the technique's findings, which provide information about the time-frequency dependence of economic growth and foreign aid, gross capital formation, export, and import in Chad. The spherical cone indicates the cone of influence (COI), which interpretation is based on. According to Zhang et al. [69], Kirikkaleli and Adebayo [33], Adebayo and Akinsola [4], and Ayobamiji and Kalmaz [16], rightward and leftward arrows pointing to the thick black shape portrays positive and negative correlation correspondingly. Furthermore, rightward-up and leftward down arrows pointing at the thick black shape illustrates that the second variable cause the first variable whereas rightward and down and leftward and up shows that the first variable causa the second variable. Additional scale 0-8 indicates the short-term, scale $8-16$ portrays the medium term, and scale 16-32 stands long-term.

In Fig. 3, at different scales between 1983 and 1986, there is proof of rightward arrows, which indicates a positive correlation between economic growth and foreign aid. Also, rightward down arrows signify that GDP growth causes foreign aid. However, between 1990 and 2015, at different scales, there is no evidence of a correlation between GDP growth and foreign aid in Chad. In Fig. 4, between 1988 and 1990, there is evidence of a positive correlation between GDP growth and gross capital formation in the medium term. However, no significant evidence was found to support the correlation between real growth and GCF from 1991 and 2014 in Chad. In Fig. 5, at different scales between 1982 and 1988, there is evidence of rightward arrows, which indicates a positive correlation between GDP growth and import. The rightward and down arrows signify that GDP growth cause import. The rightward arrows mirror the positive correlation between GDP growth and import, while rightwarddown arrows indicate that GDP growth causes import. In 


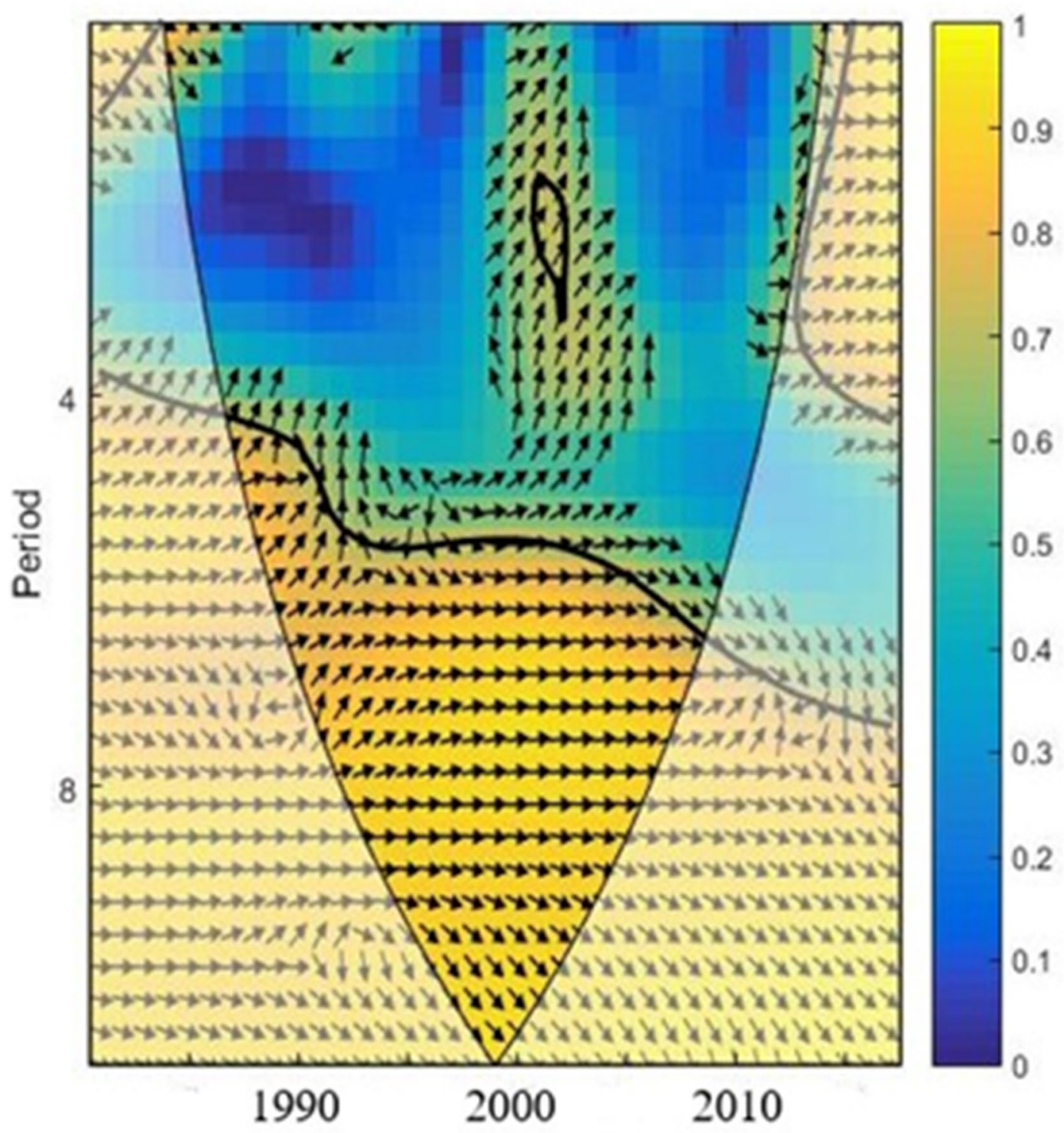

Fig. 5 Wavelet coherence between economic growth and exports of goods and services

Fig. 6, at medium and long-term between 1983 and 2011, the rightward arrows illustrate the positive interconnection between GDP growth and export in Chad. Also, in this timeframe, the rightward-down arrows show that GDP growth leads to export (Figs. 7, 8).

\section{Conclusions}

For most developing nations, foreign aid contributes significantly to economic growth. Foreign aid tends to be more effective for countries with sound economic and institutional policy initiatives. As a result, policies have been established to ensure effective and useful governance and fight corruption. Hence, this paper aims to dig into the Aid-Growth interconnection with regards to Chad deploying yearly data stretching between 1982 and 




Fig. 6 Wavelet coherence between economic growth and gross capital formation

2018. The authors deployed recent econometric techniques to investigate this linkage between foreign aid and economic growth. The ARDL bounds test revealed the existence of cointegration among the variables developed. This gives room for estimation of the ARDL long and short techniques to be utilized. The FMOLS and DOLS estimators further provide reassuring proof for the ARDL long-run result.

Moreover, to analyse the correlation and causality between economic growth and other indicators, the wavelet coherence technique was deployed. The main novelty of this technique is that it can detect correlation and causality simultaneously between time series variables. Findings from the ARDL long-run estimates depict; (i) no significant interaction exists between foreign aid and GDP growth in Chad. This result corresponds to past works $[1,15,18,38]$ Park [47] suggests that high administrative costs could be a significant factor, therefore there is a need for the cost of administration to reduce,(ii) gross capital formation in Chad does not influence GDP growth in Chad. This result does not align with previous studies [41, 46] and Adebayo and Kalmaz [5]), (iii) there is evidence of a positive link between GDP growth and import. This finding aligns with previous studies such 


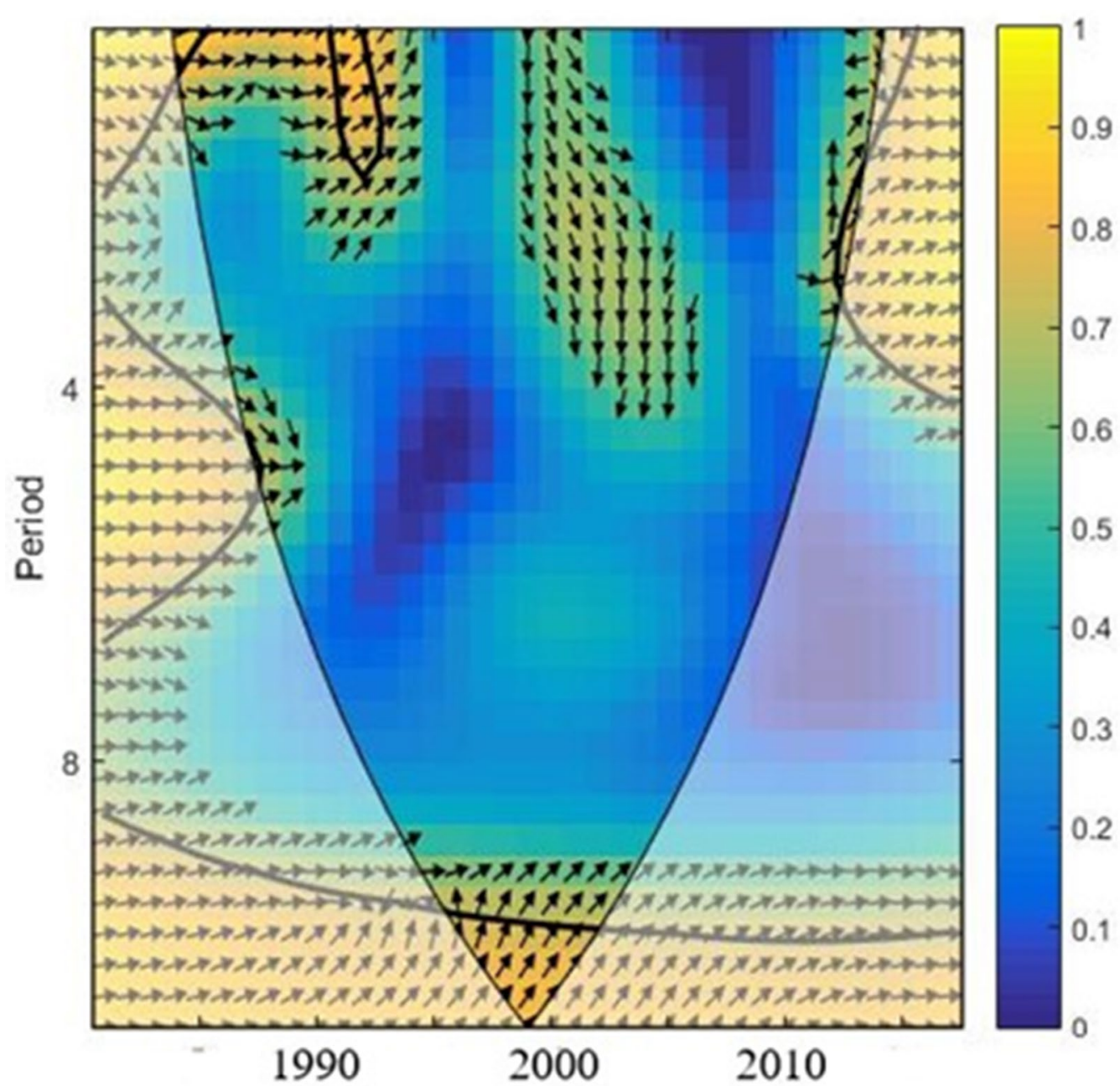

Fig. 7 Wavelet coherence between economic growth and imports of goods and services

as Alam and Bhowmik [9] and Awan and Qasim [15], (iv) export exert positive and significant influence GDP growth in Chad. This result aligns with past studies [9, 19, 46]; (v) As expected, the global financial crisis has a negative and significant impact on the economy of Chad; (v) as expected, the global financial crisis has a negative and significant impact on Chad's economy; and (vi) the short-run estimate shows that the ECM is significant, statistically indicating a quicker return to equilibrium in the event of an imbalance. Lastly, the outcomes of the wavelet coherence provide supportive evidence for the ARDL, FMOLS, and DOLS outcomes.

Based on the above findings, there is a need to evaluate the nation's economic cycle and the global economic transformation. Moreover, the government needs to make some effort to use more effective fiscal and monetary policies. For instance, effective monetary policies like reserve requirements, the discount rate, and open market operations can be implemented while fiscal policy such as effective tax structure and budgetary planning can also be implemented. Substantial macroeconomic reforms and 


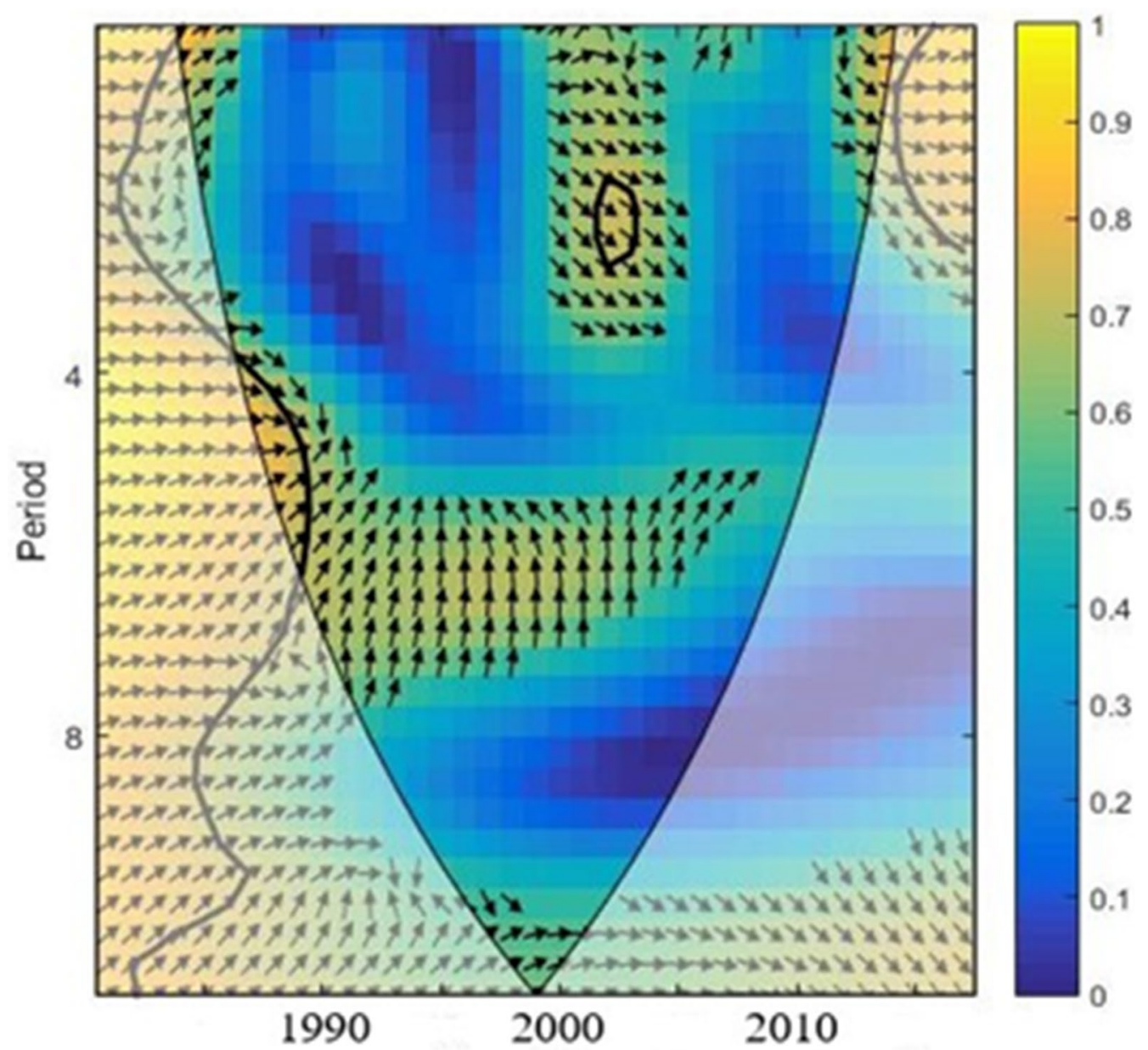

Fig. 8 Wavelet coherence between economic growth and foreign aids

economic liberalization initiatives will help distribute information and promote more investment and importation of high-tech goods and services. Both of these would make the country extremely competitive, contributing to consistent growth and increased the quality of living of the population. This study presents sound analytical results and fills gaps in the existing literature using FMOLS, DOLS, ARDL, and the current wavelet coherence technique. We suggest that future work should evaluate the relationship, as mentioned earlier in the various developing nations, to contribute to the literature.

\section{Abbreviations}

ARDL: Autoregressive Distributed Lag; CC: Control of Corruption; CRD: Banking Credit; CUSUM: Cumulative sum; CUSUMSQ: Cumulative sum of squares; DOLS: Dynamic Ordinary Least Squares; eAID: Education Aid; ECM: Error Correction Model; ELG: Export-Led Growth; FCl: Foreign Capital Inflow; FD: Financial Deepening; FD: Financial Development; FDI: Foreign Direct Investment; FMOLS: Fully Modified Ordinary Least Squares; FPI: Foreign Portfolio Investment; GCF: Gross Capital Formation; GDP: Gross Domestic Product:; GDS: Gross Domestic Savings; Gov.E: Government Effectiveness; hAID: Health
Aid; HC: Human Capital; MDGs: Millennium Development Goals; ODA: Official Development Assistance; PRIV: Privatization; PS: Price Stability; TR: Trade; UN: United Nations; V\&A: Voice and Accountability; VECM:Vector Error Correction Model; Y: Economic Growth.

\section{Acknowledgements}

Not applicable.

\section{Authors' contributions}

Every author made contribution in each of the article sections. TSA gathered the data, run the analysis and interpret the results, DK supervised the research work, and contribute to the methodology, AAA wrote the introduction and IA helped in the literature review and proof reading. All authors read and approved the final manuscript.

\section{Funding}

We declare that there is no funding received toward this study.

\section{Availability of data and materials}

The datasets analyzed during the current study are publicly available at World Bank database. 


\section{Declarations}

\section{Competing interests}

The authors declare that they have no competing interests.

\section{Author details}

${ }^{1}$ Faculty of Economic and Administrative Sciences, Department of Banking and Finance, The European University of Lefke, Lefke, Northern Cyprus, TR-10 Mersin, Turkey. ${ }^{2}$ Department of Information Technology, School of Computing and Technology, Eastern Mediterranean University, North Cyprus, Mersin 10, Turkey. ${ }^{3}$ Faculty of Economic and Administrative Science, Department of Business Administration, Cyprus International University, Nicosia, Northern Cyprus, TR-10 Mersin, Turkey. ${ }^{4}$ Department of Economics, Faculty of Economics and Administrative Science, Near East University, North Cyprus, Mersin 10, Turkey.

\section{Received: 21 December 2020 Accepted: 29 March 2021}

Published: 6 May 2021

\section{References}

1. Adams, J. (2020). Can foreign aid contribute to sustained growth? A comparison of selected African and Asian countries. World Journal of Entrepreneurship Management and Sustainable Development.

2. Adebayo TS (2020) Revisiting the EKC hypothesis in an emerging market: an application of ARDL-based bounds and wavelet coherence approaches. SN ApplSci 2(12):1-15

3. Adebayo TS, Beton Kalmaz D (2020) Ongoing debate between foreign aid and economic growth in Nigeria: a wavelet analysis. Social Science Quarterly 101(5):2032-2051

4. Adebayo TS, Akinsola GD (2021) Investigating the causal linkage among economic growth, energy consumption and co2 emissions in Thailand: An Application of the Wavelet Coherence Approach. Int J Renew Energy Dev 10(1):17-26

5. Adebayo TS, Kalmaz DB (2021) Determinants of $\mathrm{CO}_{2}$ emissions: Empirical evidence from Egypt. Environmental and Ecological Statistics. https://doi.org/ 10.1007/s10651-020-00482-0

6. BetonKalmaz D, Adebayo TS (2020) Ongoing debate between foreign aid and economic growth in Nigeria: A wavelet analysis. SocSci Q. https://doi.org/10. $1111 /$ ssqu. 1284

7. Adedokun AJ (2017) Foreign aid, governance and economic growth in SubSaharan Africa: Does one cap fit all? Afr Dev Rev 29(2):184-196

8. Aghoutane K, Karim M (2017) The impact of foreign aid on economic growth in Morocco: econometric analysis using VECM. Int J Econ Financ 9(5):87-93

9. Alam, M. M., \& Bhowmik, D. (2020). The causal relationship among export, Imports, capital formation and economic growth in Bangladesh. Journal Of Humanities And Social Science, 2279-0837, p-ISSN: 2279-0845.

10. Ali AYS, Dalmar MS, Ali AA (2018) Effects of foreign debt and foreign aid on economic growth in Somalia. Int J Econ Financ 10(11):1-95

11. Ali, M. F. M, Önder, Emrah A., (2018). How foreign aid affect developing countries: The case of Ethiopia: t.c. Türk işbirliği ve koordinasyon ajansı başkanlığıtürk cooperation and coordination agency. Avrasya etüdleri 53/2018-1 (7-39)

12. Alola, A. A., \& Kirikkaleli, D. (2020). Global evidence of time-frequency dependency of temperature and environmental quality from a wavelet coherence approach. Air Quality, Atmosphere \& Health, 1-9.

13. Apodaca, C. (2017). Foreign aid as foreign policy tool. In Oxford research encyclopedia of politics.

14. Asongu SA, Nwachukwu JC (2016) Foreign aid and governance in Africa. Int Rev Appl Econ 30(1):69-88

15. Awan AG, Qasim H (2020) The impact of external debt on economic growth of Pakistan. Global Journal of Management, Social Scienes and Humanities 6(1):30-61

16. Ayobamiji AA, Kalmaz DB (2020) Reinvestigating the determinants of environmental degradation in Nigeria. International Journal of Economic Policy in Emerging Economies 13(1):52-71

17. BTI (2020). Chad Country Report 2020

18. Dong, Y., \& Fan, C. (2020). The role of China's aid and ODI in the economic growth of African countries. Emerging Markets Review, 100713.
19. Ee CY (2016) Export-led growth hypothesis: empirical evidence from selected Sub-Saharan African countries. Procedia Economics and Finance 35(2):232-240

20. Ehigiamusoe KU, Lean HH (2019) Foreign capital inflows and economic growth in Nigeria: Any Nexus? J Afr Bus 20(4):455-471

21. Emini, C. A. (2020). Impacts of the 2014-16 drop in oil prices on child poverty in Chad and options for a policy response: Analysis using a recursive dynamic CGE model with fully integrated microsimulations. Retrieved from: https://www.gtap.agecon.purdue.edu/resources/download/9913. pdf

22. Entreprises, E. (2021, February). Foreign direct investment (FDI) in Chad. Retrieved February 10, 2021, from https://www.nordeatrade.com/en/ explore-new-market/chad/investment?vider_sticky=oui\#: :text=The\% 20majority\%20of\%20FDl\%20goes,United\%20Kingdom\%20and\%20Sou th\%20Korea.

23. Evelyn W., \& Bruno S.S. (2019). Exploring the nature, motives, and implications of foreign capital in Africa, World Development Perspectives, Volume 14,100108

24. Fashina OA, Asaleye AJ, Ogunjobi JO, Lawal Al (2018) Foreign aid, human capital and economic growth nexus: Evidence from Nigeria. Journal of International Studies 11(2):104-117

25. Gadom GD, Kountchou AM, Araar A (2018) The impact of oil revenues on wellbeing in Chad. Environ Dev Econ 23(5):591-613

26. Goupillaud P, Grossmann A, Morlet J (1984) Cycle-octave and related transforms in seismic signal analysis. Geoexploration 23(1):85-102

27. Hoinathy R, Janszky B (2017) The Extractive Industries Transparency Initiative (EITI): The latest attempt at governing the extractive industries in Chad. The Extractive Industries and Society 4(4):825-832

28. Hussain I, Khan Z, Khan MI, Khalid S, Kiran A, Hussain T (2017) Long run and short run relationship among gross domestic saving, net bilateral foreign aid, external debt and economic growth in Pakistan. Dynamics of Economics 1(1):1-7

29. IFAD. (2019). Chad. Retrieved February 28, 2021, from https://www.ifad. org/en/web/operations/country/id/chad

30. Juselius K, Reshid A, Tarp F (2017) The real exchange rate, foreign aid and macroeconomic transmission mechanisms in Tanzania and Ghana. The Journal of Development Studies 53(7):1075-1103

31. Kalmaz DB, Kirikkaleli D (2019) Modeling CO 2 emissions in an emerging market: empirical finding from ARDL-based bounds and wavelet coherence approaches. Environ SciPollut Res 26(5):5210-5220

32. Kaya I, Kaya O (2020) Foreign aid, institutional quality and government fiscal behavior in emerging economies: An empirical investigation. Q Rev Econ Finance 76:59-67

33. Kirikkaleli, D., \& Adebayo, T. S. (2020). Do renewable energy consumption and financial development matter for environmental sustainability? New global evidence. Sustainable Development.

34. Kirikkaleli, D., Adebayo, T. S., Khan, Z., \& Ali, S. (2020). Does globalization matter for ecological footprint in Turkey? Evidence from dual adjustment approach. Environmental Science and Pollution Research, 1-9.

35. Lee J, Strazicich MC (2003) Minimum Lagrange multiplier unit root test with two structural breaks. Rev Econ Stat 85(4):1082-1089

36. Liaqat S, Ahmad HK, Kifle T, Alauddin M (2019) The Aid, Macroeconomic Policy Environment and Growth Nexus: Evidence from Selected Asian Countries. The Lahore Journal of Economics 24(1):83-102

37. Mansoor S (2018) Aid volatility, macroeconomic policy and economic growth in Pakistan. Pakistan Business Review 20(1):82-90

38. Maruta, A. A., Banerjee, R., \& Cavoli, T. (2019). Foreign aid, institutional quality and economic growth: Evidence from the developing world. Economic Modelling.

39. Mbah S, Amassoma D (2014) The linkage between foreign aid and economic growth in Nigeria. International Journal of Economic Practices and Theories 4(6):1007-1017

40. Mohapatra, G., Giri, A. K., \& Sehrawat, M. (2016). Foreign aid, macroeconomic policies and economic growth nexus in India: An ARDL bounds testing approach. Theoretical \& Applied Economics, 23(4).

41. Mustafa, M. E., Elshakh, M. M., \& Ebaidalla, E. M. (2019). Does foreign aid promote economic growth in Sudan? Evidence from ARDL Bounds Testing Analysis. Journal of Economic Cooperation \& Development, 40(3). 
42. Nowak-Lehmann F, Martínez-Zarzoso I, Herzer D, Klasen S, Cardozo A (2013) Does foreign aid promote recipient exports to donor countries? Rev World Econ 149(3):505-535

43. Olanrewaju VO, Adebayo TS, Akinsola GD, Odugbesan JA (2021) Determinants of Environmental Degradation in Thailand: Empirical Evidence from ARDL and Wavelet Coherence Approaches. Pollution 7(1):181-196

44. Odugbesan, J. A., \& Adebayo, T. S. (2020). Modeling CO 2 emissions in South Africa: empirical evidence from ARDL based bounds and wavelet coherence techniques. Environmental Science and Pollution Research, 1-13.

45. Ott, Z. (2019, December 17). The ways that the us benefits from foreign aid to Chad. Retrieved February 28, 2021, from https://borgenproject.org/u-s-benef its-from-foreign-aid-to-chad/

46. Ouedraogo R, Sourouema WS (2018) Fiscal policy pro-cyclicality in SubSaharan African countries: The role of export concentration. Econ Mode 74:219-229

47. Park, J. D. (2019). Assessing the role of foreign aid, donors and recipients. In ReInventing Africa's Development (pp. 37-60). Palgrave Macmillan, Cham.

48. Pesaran MH, Shin Y (1998) An autoregressive distributed-lag modelling approach to cointegration analysis. EconomSocMonogr 31:371-413

49. Pesaran MH, Shin Y, Smith RJ (2001) Bounds testing approaches to the analysis of level relationships. J ApplEconomet 16(3):289-326

50. Pham NS, Pham TKC (2020) Effects of foreign aid on the recipient country's economic growth. J Math Econ 86:52-68

51. Phillips PC, Hansen BE (1990) Statistical inference in instrumental variables regression with I (1) processes. Rev Econ Stud 57(1):99-125

52. Rjoub H, Odugbesan JA, Adebayo TS, Wong WK (2021) Sustainability of the Moderating Role of Financial Development in the Determinants of Environmental Degradation: Evidence from Turkey. Sustainability 13(4):1844

53. Sethi N, Bhujabal P, Das A, Sucharita S (2019) Foreign aid and growth nexus: Empirical evidence from India and Sri Lanka. Economic Analysis and Policy 64:1-12

54. Sothan S (2018) Foreign aid and economic growth: evidence from Cambodia. $J$ Int Trade Econ Dev 27(2):168-183

55. Tang KB, Bundhoo D (2017) Foreign aid and economic growth in developing countries: Evidence from Sub-Saharan Africa. Theoretical Economics Letters 7(05):1473

56. Tekin RB (2012) Economic growth, exports and foreign direct investment in Least Developed Countries: A panel Granger causality analysis. Econ Model 29(3):868-878

57. Tekin, R. B. (2019). A note on causality relatıons among economıc growth, development assistance and trade openness in low income countries. Marmara University Journal of Economic \& Administrative Sciences, 41(2).
58. Terefe KD (2018) Drivers of economic growth in Ethiopia: Does foreign aid and policy complementarity matter? Journal of Economics and International Finance 10(8):95-110

59. Torrence C, Compo GP (1998) A practical guide to wavelet analysis. Bull Am Meteor Soc 79(1):61-78

60. Udemba EN, Güngör H, Bekun FV, Kirikkaleli D (2021) Economic performance of India amidst high CO2 emissions. Sustainable Production and Consumption 27:52-60

61. Umar M, Ji X, Kirikkaleli D, Xu Q (2020) COP21 Roadmap: Do innovation, financial development, and transportation infrastructure matter for environmental sustainability in China? J Environ Manage 271:111026

62. UNDP (2019) Human Development Report 2019: Chad. New York: UNDP. Retrieved from: http://hdr.undp.org/en/countries/profiles/TCD

63. UNCTAD (2020) WORLD INVESTMENT REPORT 2020. Retrieved January 10, 2021, from https://unctad.org/system/files/officialdocument/wir2020_overv iew_en.pdf

64. Wamboye E, Adekola A, Sergi BS (2014) Foreign aid, legal origin, economic growth and Africa's least developed countries. Prog Dev Stud 14(4):335-357

65. Whang T, Kim Y, Han JT, Kim HJ (2019) US foreign aid and economic policy concessions. Policy Studies 40(1):58-79

66. World bank (2019). Chad indicators. Retrieved from https://data.worldbank. org/country/chad

67. World bank (2019). Net official development assistance and official aid received (current US\$). Retrieved from: https://data.worldbank.org/indicator/DT.ODA. ALLD.CD

68. Yiew TH, Lau E (2018) Does foreign aid contribute to or impeded economic growth? Journal of International Studies 11(3):21-30

69. Zhang, L., Li, Z., Kirikkaleli, D., Adebayo, T. S., Adeshola, I., \& Akinsola, G. D. (2021). Modeling CO 2 emissions in Malaysia: an application of Maki cointegration and wavelet coherence tests. Environmental Science and Pollution Research, 1-15.

70. Zivot E, Andrews DWK (2002) Further evidence on the great crash, the oil-price shock, and the unit-root hypothesis. Journal of business \& economic statistics 20(1):25-44

\section{Publisher's Note}

Springer Nature remains neutral with regard to jurisdictional claims in published maps and institutional affiliations.

\section{Submit your manuscript to a SpringerOpen ${ }^{\circ}$ journal and benefit from:}

- Convenient online submission

- Rigorous peer review

- Open access: articles freely available online

- High visibility within the field

- Retaining the copyright to your article

Submit your next manuscript at springeropen.com 